\title{
THE MINORITY'S DUTY OF LOYALTY IN CLOSE CORPORATIONS
}

\section{J.A.C. HETHERINGTON*}

We are accustomed to thinking of corporate stock primarily as property, and of stockholders, particularly minority stockholders, as free agents in the exercise of their rights as property owners. The purpose of this article is to show that there are situations in which minority shareholders, like other holders of contract and property rights, may be obligated when exercising their rights as owners of stock to take the interests of other parties into account. The arguments for this proposition are based on principles which are well established in corporation law and in commercial law. The corporation law principle is the familiar duty of loyalty which is imposed on management and controlling shareholders; the commercial concepts are those requiring commercially reasonable behavior and the avoidance of unconscionable conduct in business dealings. The corporation and commercial law concepts are discussed briefly in parts I and II of the article, and in part III the principles developed in the preceding parts are related to the conduct of minority shareholders in close corporations in certain types of situations.

\section{I}

\section{The Fiduciary Duty of Individuals Who Control}

The most significant developments in corporation law during the past decade have occurred in the area of management and insider responsibilities. In the wake of SEC v. Texas Gulf Sulphur Co. ${ }^{1}$ and its progeny, ${ }^{2}$ commentators have exhaustively examined and analyzed the possible and probable impact of this developing body of law on the securities market and on the business community generally. ${ }^{3}$ Securities trading is only one dimension of the broader subject of

* Professor of Law, University of Virginia. A.B. 1950, Dartmouth College; LL.B. 1953, Cornell University; LL.M. 1956, University of California, Berkeley.

1. 401 F.2d 833 (2d Cir. 1968), cert. denied, 394 U.S. 976 (1969).

2. SEC v. Texas Gulf Sulphur Co., 446 F.2d 1301 (2d Cir. 1970), cert. denied, 404 U.S. 1005 (1971); Reynolds v. Texas Gulf Sulphur Co., 309 F. Supp. 548 (D. Utah 1970).

3. For a recent analysis and review of the developing law of management and insider responsibilities, see Dooley, The Effects of Civil Liability on Investment Banking and the New Issues Market, 58 VA. L. Rev. 776, 810-33 (1972). The volume of literature commenting on the subject is huge. See the references cited in H. HenN, Law OF Corporations $\S 298$ nn.3, 4,14 (1970). 
management responsibility to the corporation and its shareholders. Fiduciary responsibility embraces the entire range of management functions and activities, from the duty of competence and diligence to situations in which management's personal interests conflict with those of the enterprise and its shareholders. Judicial opinions dealing with the subject are often marked by a moral tone which is much less apparent or altogether lacking in opinions treating other corporate and commercial law subjects. Defendants whose conduct is found to violate the duty of loyalty are not only legally liable in the same manner as a person who fails to perform a contract or other legal obligation, but, in addition, their conduct is condemned as unethical and morally reprehensible. ${ }^{4}$

The fiduciary responsibility of management has two dimensions. First, it embodies an obligation to manage the enterprise competently and profitably. Second, it imposes an obligation on managers not to exercise the prerogatives of control for personal gain or to advance the interests of one group of owners at the expense of another. The scope of these obligations cannot be defined precisely. It emerges from a ruling-out process in the case law by which certain types of conduct have been found inappropriate for those individuals charged with "fiduciary" responsibilities. The cases may be conveniently separated into three distinct categories.

The first category involves situations in which management, in taking action on behalf of the corporation, subordinates the corporation's interests to a conflicting outside interest, usually management's own. The partially owned subsidiary cases are illustrative: In this type of case, the parent-controlled management of the subsidiary acts on the subsidiary's behalf in a manner which is detrimental to the subsidiary if it is viewed as a separate entity. ${ }^{5}$ From the standpoint of the

4. The classic expression of the duty of loyalty among co-adventurers is Judge Cardozo's comment: "Not honesty alone, but the punctilio of an honor the most sensitive, is . . . the standard of behavior. As to this there has developed a tradition that is unbending and inveteratc." Meinhard v. Salmon, 249 N.Y. 458, 464, 164 N.E. 545, 546 (1928). The applicability of this standard to corporate management is, of course, well established. See generally H. HENN, supra note $3, \S 238$. The moral aspect of the legal principle is evident in the opinion of Chief Judge Fuld in Diamond v. Oreamuno, 24 N.Y.2d 494, 248 N.E.2d 910, 301 N.Y.S.2d 78 (1969), an insider trading case, where he approvingly quotes Professor Ballantine's statement that "[d]ishonest directors should not find absolution from retributive justice by concealing their identity from their victims under the mask of the stock exchange." Id. at 503, 248 N.E.2d at 915, 301 N.Y.S.2d at 85, citing H. Ballantine, Corporations 216 (1946).

5. See, e.g., Lebold v. Inland Steel Co., 125 F.2d 369 (7th Cir. 1941). Cf. Case v. New York Cent. R.R., 15 N.Y.2d 150, 204 N.E.2d 643, 256 N.Y.S.2d 607 (1965). 
subsidiary's minority shareholders, the conflicting interest of the parent is an outside adverse interest promoted by the subsidiary's own management.

The second category of management responsibility cases involves the diversion of business opportunities from the corporation to the management group. Liability arises from the finding that the diverted opportunity was one in which the corporation had an expectant interest, usually as a result of its prior business activities. The relationship between the corporation's existing business and the opportunity defines-somewhat vaguely-the reach of the rule. ${ }^{6}$ The rule applies only to management and to the controlling shareholders; a noncontrolling shareholder who is not a director, officer or employee appears to have no duty to refrain from intercepting a business opportunity in which the corporation might be interested, provided he does not act on the basis of confidential information. ${ }^{7}$

The third category differs from the first two in that liability is not dependent upon or related to management or control of the corporation. These cases involve the personal use by directors, officers and employees of information acquired by them through their positions in the corporation. ${ }^{8}$ Confidential information obtained through an individual's corporate office is business property of the corporation, and personal use of such information may be considered a misappropriation of a corporate asset. The cases in this category may be divided into two classes. The first includes the personal use of information which results in direct damage or injury to the corporation, such as in the case of misappropriation of a trade secret or theft of customer lists for use in a competing business. ${ }^{9}$ The second involves

6. It may be difficult to determine the scope of the corporation's interest in business opportunities which the law will or should protect against management appropriation. See Johnston v. Greene, 35 Del. Ch. 479, 121 A.2d 919 (1956). Where the corporate interest and the intent to misappropriate are clear, punitive damages have been awarded. See International Bankcr's Life Ins. Co. v. Holloway, 368 S.W.2d 567 (Tex. 1963).

7. See generally H. HenN, supra note $3, \S 237$; W. CARY, Cases and Materials on Corporations 666-81 (4th ed. 1969). None of the authorities cited by these authors appear to involve an effort to impose the "corporate opportunity doctrine" on minority shareholders who are not directors, officers, or employees. In this respect a shareholder's position differs from that of a partner, who may neither compete with the partnership nor appropriate a "partnership opportunity" to his own use. J. Crane \& A. Bromberg, LAw of PARTNership $§$ 68, at 391 (1968).

8. A widely cited early case involving common law liability for insider trading is Brophy v. Cities Serv. Co., 31 Del. Ch. 241, 70 A.2d 5 (1949). The leading recent case is Diamond v. Oreamuno, 24 N.Y.2d 494, 248 N.E.2d 910, 301 N.Y.S.2d 78 (1969).

9. See generally H. Henn, Agency, Partnership, ANd Other Unincorporated BusiNESS ENTERPRISES 81-92 (1972). 
the use of inside information which does not cause any direct injury or loss to the corporation; for this reason, it is arguable that the insider misappropriated nothing of value to the corporation. The insider stock trading cases often involve exactly this situation. The corporation usually suffers no direct loss or injury from insider stock transactions made on the basis of confidential information. ${ }^{10}$ Professor H.G. Manne has argued that buyers and sellers of securities are, in fact, betting on the accuracy of their analysis and information concerning the security being traded, that generally neither party to a securities transaction on a stock exchange or in the over-the-counter market need disclose his information to the other, and that insider trading should not be subject to special rules. ${ }^{11}$ However, the course of the law has now been clearly set against such insider activities, ${ }^{12}$ and the judicial rhetoric is thunderously moral. ${ }^{13}$

In effect, the insider trading cases create a new fiduciary responsibility which runs from one group of shareholders-those with inside information material to stock prices-to other shareholders and potential shareholders. Whenever information material to the value of a security is not generally available to securities traders, the market is less likely to price that security at a level which accurately reflects its worth in relation to other securities. The resulting inaccuracy of the market price is corrected when the previously undisclosed information becomes known. As a result of the price correction some traders get a windfall-those who sold before a price decline or bought before a rise-and those who did the opposite will suffer a

10. This was preeisely the case in Diamond v. Oreamuno, 24 N.Y.2d 494, 248 N.E.2d 910 , 301 N.Y.S.2d 78 (1969), where it appeared that insiders had sold their stock in response to confidential information indicating that the corporation's earnings had been substantially reduced because of an increase in the cost of services rendered by its principal supplier. The price of the company's stock dropped from $\$ 28$ to $\$ 11$ when the news became publie, and the insiders were held liable to the corporation for the difference between the price that they were paid prior to disclosure and the price which they would have received after it. The court conccded that the corporation had suffered no direct financial loss because of the insiders' trading and emphasized the deterrent aspect of the rule which is analogous to the prohibition against a trustec's personal use of information acquired in his capacity as trustee. Id. at 498, 248 N.E.2d at 912, 301 N.Y.S.2d at 81.

11. The arguments for allowing insider trading have been powerfully presented in $\mathrm{H}$. ManNe, INSider TRAding and the Stock Market (1966). For a revicw of Professor Manne's book, see Hetherington, Insider Trading and the Logic of the Law, 1967 WIs. L. Rev. 720. Generally, insider trading inflicts no direct monetary loss on the corporate cmployer. See, e.g., Diamond v. Oreamuno, 24 N.Y.2d 494, 248 N.E.2d 910, 301 N.Y.S.2d 78 (1969).

12. The views expressed in Diamond v. Oreamuno, 24 N.Y.2d 494, 248 N.E.2d 910, 301 N.Y.S.2d 78 (1969), have prevailed.

13. See note 4 supra. 
loss. It is apparent, therefore, that insider trading itself injures no one, but that the withholding of information creates the possibility for fortuitous profits and losses, and that corporate insiders and their associates on the whole have a better chance than outsiders to make profits. There is no doubt that trading on confidential information offends the courts' sense of fairness, and probably that of stockholders and of the public generally. For this reason, the prohibition of insider trading undoubtedly helps to maintain public confidence in the integrity of the market (in other words, in the accuracy of market prices). In addition, by depriving management of an incentive to delay disclosure in order to make trading profits, it may expedite the flow of price-relevant information from securities issuers to the market. Finally, since the purpose and function of the rule is to deter, rather than to compensate for actual loss caused by the insiderdefendant, the limits of the liability tend to be flexible and unstable. Presumably liability will be extended to the point to which the courts think it needs to be carried in order to deter. Thus far only corporate insiders and those persons to whom they have given inside information have been held liable. ${ }^{14}$ It remains to be seen whether it is feasible, desirable or necessary to extend liability beyond this group.

For present purposes, it is sufficient to note that existing precedents impose fiduciary obligations: (1) on corporate managers and controlling shareholders when they act on behalf of the corporation or appropriate to themselves business opportunities which would be of interest to an enterprise engaged in the corporation's business; and (2) on all corporate insiders when they attempt to profit personally from information gained through their connection with the corporation. The first obligation clearly runs to the corporation; the second may run either to the corporation alone, as in the case of misappropriation of business information, or to both the corporation and those persons with whom the insider deals, as in the case of insider trading.

\section{II}

The Duty to Act "Fairly"IN Non-Fiduciary Business

\section{RELATIONSHIPS}

In ordinary business dealings between business organizations and

14. In the Texas Gulf Sulphur case, insiders were held liable for the profits made by those individuals whom they had informed (tippees), but not for the gains of the tippees' tippees. Where should liability end? The district court in the Texas Gulf Sulphur case, considering the problem to be one of deterrence, thought it had gone far enough. 312 F. Supp. 77, 95 (S.D.N.Y. 1970). The tippees may themselves be liable. See Ross v. Licht, 263 F. Supp. 395 (S.D.N.Y. 1967). 
individuals, neither party to a transaction is a fiduciary of the other. The usual transaction is, of course, an exchange in which goods or services are bought and sold. The law does not make the participants in such transactions guardians of each other's interests. The legal obligation of each is simply to perform the specific obligation he has undertaken. ${ }^{15}$ The distinction between this relationship and the relationship existing between corporations and the individuals who control and manage them seems elear.

This apparently clear distinction is neither as clear nor as great as it initially appears. In the name of good faith, fair dealing, and similar concepts, the courts have imposed limits on the bargaining process and on the exercise of contraet ${ }^{16}$ and property ${ }^{17}$ rights in nonfiduciary business dealings. The difficulty with such criteria, when they are used as a basis for determining the legality of business conduct, is the inevitable imprecision of the standards. This problem has received considerable attention in current periodical literature dealing with the Uniform Commercial Code. ${ }^{18}$ What is "unconscionable" conduct in commercial and consumer transactions? What do "commercially reasonable" and "good faith" mean in business transactions? The difficulty is compounded by the fact that the standards of conduct required by these criteria vary with the situation to which they are applied. ${ }^{19}$ Yet, however unsatisfactory these flexible concepts

15. Of course, disagreements may arise concerning the scope of the obligation which the contracting parties have undertaken. Litigation dealing with such questions is an important part of contract law. For a collection of cases involving issues concerned with the nature and scopc of contractual obligations, see L. Fuller \& M. EISENBERG, BASIC CONTRACT LAw 618-49 (3d ed. 1972).

16. These obligations are not confined to situations in which a final agreement is reached between the parties. They arise in the course of the negotiating process even if no bargain is ever made. See generally Henderson, Promissory Estoppel and Traditional Contract Doctrine, 78 YALE L.J. 343 (1969).

17. For a discussion of restraints on the abuse of property rights in real property, see $5 \mathrm{R}$. Powell, Real Property II 704-07 (1971).

18. See. e.g., Ellinghaus, In Defense of Unconscionability, 78 YALE L.J. 757 (1969); Farnsworth, Good Faith Performance and Commercial Reasonableness under the Uniform Commercial Code, 30 U. CHI. L. REv. 666 (1963); Leff, Unconscionability and the Code-The Emperor's New Clause, 115 U. PA. L. REv. 485 (1967); Murray, Unconscionability: Unconscionability, 31 U. PITT. L. REv. 1 (1969); Summers, "Good Faith" in General Contract Law" and the Sales Provisions of the Uniform Commercial Code, 54 VA. L. REv. 195 (1968).

19. In the UCC some standards are explicitly direeted toward particular types of business dealing. See, for example, the special definition of good faith between merchants. UNIFORM Commercial CODE $\S 2-103(1)(b)$. Of course, courts commonly take the circumstances of the parties into consideration in applying such criteria to individual behavior. A notable recent example which has provoked much discussion is Williams v. Walker-Thomas Furniture Co., 
of fairness are when subjected to intensive technical analysis, ${ }^{20}$ they at least establish that in a variety of business situations, property and contract rights must be exercised in conformity with a minimum standard of business morality. The questions involved in a determination of whether a particular exercise of contract or property rights is made in good faith or is commercially reasonable are illustrated in cases arising from situations in which one party to a consensual ongoing relationship attempts to exercise his apparently unqualified right to discontinue the relationship. In a variety of contexts the courts have restricted the power to terminate.

The retaliatory eviction cases are good examples of situations in which courts have limited the right of a party to a consensual contractual relationship to end the arrangement. A number of courts have now held that a landlord may not terminate a tenancy at will in retaliation for the conduct of the tenant in reporting the landlord's violation of applicable housing regulations. ${ }^{21}$ These decisions cannot be reconciled with the conventional analysis of tenancies at will. The tenant under such an arrangement has no legal right to an extension of the tenancy beyond each rental period. Provided he complies with applicable procedural requirements, the owner appears to be entitled to repossess the property at any time.

In explaining the difference betwcen the common law property rule and the newer, more restrictive termination standard, one court observed that, although a property owner may terminate a tenancy at will for any or no reason, he may not evict "simply" because the tenant has reported housing violations to the appropriate authorities. ${ }^{22}$ It is probably true that if property owners in a tight housing market may evict tenants who report housing violations, some tenants will be deterred from reporting infractions, and the effectiveness of remedial housing legislation is likely to be reduced. Eviction under these circumstances would therefore tend to frustrate the public policy expressed in the legislation. Nevertheless, limiting the property owner's right to terminate results in a significant alteration of the

350 F.2d 445 (D.C. Cir. 1965). The difficulties raised by cases of this type are extensively treated in the authorities cited in note 18 supra.

20. In particular, see Leff, supra note 18.

21. See, e.g., Edwards v. Habib, 397 F.2d 687 (D.C. Cir. 1968); Dickhut v. Norton, 45 Wis. 2d 389, 173 N.W.2d 297 (1970), noted in 54 MARQ. L. REv. 239 (1971). See generally McElhaney, Retaliatory Evictions: Landlords, Tenants and Law Reform, 29 MD. L. REv. 193 (1969); Note, Retaliatory Eviction: The Tenant's Right to Challenge the Landlord's Motive, 21 SYRACUSE L. REv, 986 (1970).

22. Dickhut v. Norton, 45 Wis. 2d 389, 399, 173 N.W.2d 297, 302 (1970). 
traditional relationship between landlord and tenant. The tenant has achieved a tenure that he did not have before. There seems to be no obvious or convincing reason for distinguishing between a tenant's reporting housing violations and a tenant's other lawful or constitutionally protected conduct of which the owner may disapprove. The tenant's interest in the continuation of the tenancy at will has become an expectancy which, under some circumstances, the law now protects against "unconscionable" termination-that is, termination which is motivated by a desire to punish and which therefore is not good faith performance or commercially reasonable behavior. ${ }^{23}$ In other words, under some circumstances the legality of the exercise of property rights may be determined by the motives of the acting party. Certain motives-for example, retaliation for conduet favored by the law-are contrary to public policy, and the exercise of property rights, such as eviction, in furtherance of those motives is consequently unlawful..$^{24}$

Retaliatory cancellations of insurance policies may present similar problems. For example, in 1968, the Court of Appeals for the Sixth Circuit held that a dental malpractice insurer could not cancel the policy of its dentist-insured in retaliation for his testifying in a malpractice case against another dentist whom it also insured. ${ }^{25}$ In

23. The tenant may, as a result, also be protected against reasonable behavior by the landlord. Suppose, for example, that the landlord who has been prevcnted from collecting rent because of housing code violations, as in Brown v. Southall Realty Co., 237 A.2d 834 (D.C. Ct. App. 1968), decides not to correct the violations, but instead to withdraw the premises lrom the market. In such a case, the landowner may evict only if his good faith is established-the landlord must show that his motive in seeking to evict the tenant is not based on the tcnant's failure to pay the rent. Robinson v. Diamond Housing Corp., 463 F.2d 853, 865 (D.C. Cir. 1972).

24. It seems prudent to confine the limitations on the property owner's right to terminate discussed in the text to cases in which there is an existing economic relationsbip between the landlord and the tenant. For example, if a landlord is given a choice between two prospcetivc tenants, one of whom is known by the landlord to be a person who has reported housing violations in the past on other properties, the landlord could probably freely and frankly choose the other. Apart from special situations where considerations such as race may be proscrihed, suppliers and buyers of goods and services probably have more freedom in the selection of those persons with whom they will deal, than in cases where they are involvcd in an ongoing relationship. The latter circumstances give rise to expeetations of reasonable behavior which, as the cited cases indicate, may be protected against some types of "unfair" response.

25. L'Orange v. Medical Protective Co., 394 F.2d 57 (6th Cir. 1968), noted in 54 Iown L. Rev. 649 (1969). Contra, Camp v. Aetna Ins. Co., 170 Ga. 46, 152 S.E. 41 (1930) (insurer's motive in cancelling immaterial). Compare L'Orange v. Medical Protective Co., supra, with NLRB v. Scrivener, 405 U.S. 117 (1972), where the Supreme Court held that an employer may not retaliate against employees who give written statements in connection with an unfair labor practice investigation, despite the fact that immunity for such conduct was not directly provided 
reversing the district court's dismissal of the complaint, the court of appeals stated that, although the policy provided that the insurer was entitled to cancel at any time, if the plaintiff could show that the insurer's purpose was to intimidate him, the cancellation would be set aside. ${ }^{26}$ Clearly, the alleged reason for the cancellation was not directly related to the risk assumed by the insurer on its contract with the particular insured. Apart from the insurer's allegedly punitive motive, its business reason for exercising its cancellation privilege could have been to deter other insureds from testifying against its policyholders. Discouraging insured dentists from testifying against each other in malpractice cases could be in the economic interest of the company and all its insureds; however, in the court's view, this rationale did not justify the cancellation, because any benefit to the insurer and its policyholders from discouraging the plaintiff and other dentists from testifying in malpractice litigation would be obtained at the expense of a strong public interest in having testimony fully available to the courts, particularly in medical malpractice cases. ${ }^{27}$ The result of the case is a clear limitation on the use by the insurer of its explicit right to cancel under the policy: It is prevented from exercising a contract right for a permissible business purpose (reducing its exposure to liability) because of the putative impact of the cancellation both on the behavior of the plaintiff insured ${ }^{28}$ and the actions or the conduct of other policyholders who might learn of the company's response.

In both the eviction and the cancellation cases, the courts found a public policy that strongly supported the conduct of one party which had led the other party to attempt to discontinue the supposedly consensual relationship. ${ }^{29}$ It is not clear whether the same results

for by statute. The result is similar to that in the L'Orange case. The decision is based directly on a public policy protecting employees who assist investigations of violations of federal law. The statute itself prohibits employer retaliation against employees who actually file grievances under the Act. National Labor Relations Act $\S 8(a)(4), 29$ U.S.C. $\$ 158(a)(4)$ (1970). See also NLRB v. Marine \& Shipbuilding Workers Union, 391 U.S. 418 (1967), holding that while a union's power to discipline its members is protected under the National Labor Relations Act, it may not exercise that power against a member who has filed a grievance under the Act against the union, where the grievance "touches a part of the public domain covered by the Act." Id. at 428.

26. 394 F.2d at 63 .

27. Id. at 61-62. The court referred to the "conspiracy of silence" in such cases. Id. at 62 n.2, citing Cohn, Medical Malpractice Litigation, 52 A.B.A.J. 32 (1966).

28. At the time when the insured's policy was cancelled, a motion for a new trial was pending in the case in which he had testified. 394 F.2d at 59.

29. Another area in which the problem of abusive exercise of contract rights has attracted 
would have been reached if the retaliation had been aimed at conduct which, although lawful, was not protected by a strong and specific public interest. ${ }^{30}$ The exercise or threat to exercise property and contract rights in order to influence the lawful conduct of others is a familiar and often legitimate bargaining tactic in commercial dealings. Generally, the fact that one party's conduct is lawful or even constitutionally protected does not mean that those persons who deal with him may not disapprove of the conduct and discontinue their business relationship because of that disapproval. It is difficult to state in general terms when pressure of this kind ceases to be a permissible bargaining tactic. ${ }^{31}$ A similar type of economic pressure was involved in American Bank \& Trust Co. v. Federal Reserve Bank ${ }^{32}$ where the Supreme Court held that it would be unlawful for a federal reserve bank to accumulate checks drawn on a bank which

considerable attention in recent years is franchise termination. See Gellhorn, Limitations on Contract Termination Rights-Franchise Cancellations, 1967 DuKE L.J. 465.

30. The cases involving nonrenewal of annual employment contracts of nontenured teachers present similar problems. The Supreme Court has held that a nontenured teacher at a state institution is not entitled to a hearing when he is denied a contract for the following year. Board of Regents of State Colleges v. Roth, 408 U.S. 564 (1972). The Court pointed out that the state had not in any way disparaged the teacher's professional reputation but merely had not renewed a consensual relationship which had expired. In the posture in which it reached the Supreme Court, the case did not present the question whether renewal could be denied if it were shown that the reason for nonrenewal was the institution's disapproval of the constitutionally protected conduct of the teacher. Id. at 574 . For a survey of the cases in related areas involving protection of economic interests against summary termination without a prior opportunity to be heard, see Comment, The Growth of Procedural Due Process into a New Substance: An Expanding Protection for Personal Liberty and a "Specialized Type of Property . . . in our Economic System," 66 Nw. U.L. Rev. 502 (1971).

31. An instructive comparison may be made of two cases dealing with the question of whether or not a supplier who has been sued by a customer for violation of the anti-trust laws may, in retaliation for the bringing of the suit by its customer, refuse to continue dealing with him. In House of Materials, Inc. v. Simplicity Pattern Co., 298 F.2d 867 (2d Cir. 1962), the Second Circuit held that such a refusal was not a Sherman Act violation on the facts and was not actionable as a tort, although the district court had found that the purpose of discontinuing relations with the plaintiff was retaliatory. $I d$. at 869 . The court of appeals said:

"fundamental assumptions in free business enterprise," including the belief that "cach business enterprise must be free to select its business relations in its own interest," may justify or excuse the act of one who causes harm to another as a collateral consequence of his refusal to continue a business relation terminable at will. Id. at 872 .

On the other hand, in Bergen Drug Co. v. Parke, Davis \& Co., 307 F.2d 725 (3d Cir. 1962),

the Third Circuit issued an injunction against such retaliation. The court of appeals stated:

The point plaintiff convincingly makes is that it will be unable to secure the cooperation of other wholesalers and of retailers to be witnesses because they fear the same sort of retaliatory action that plaintiff has experienced. Certainly, a court can act where a party's conduct is calculated to frustrate litigation. Id. at 728.

32. 256 U.S. 350 (1921). 
was not a member of the federal reserve system and then to present them at one time for payment, where the purpose of the practice was to embarrass the drawee and thereby to force it to join the federal reserve system. Ordinarily, of course, the holder of a draft is free to present it or to delay presentation at its pleasure. Counsel for the reserve bank argued that a creditor cannot be prevented from foreclosing a mortgage "because he acted from disinterested malevolence and not from a desire to get his money." ${ }_{33}$ The court responded that "most rights are qualified," illustrating the point by saying that a man has a right to give his money away, but if he does so "to induce another to steal or murder, the purpose of the act makes it a crime." ${ }^{44}$ The court characterized the alleged conduct as "warfare" against the state banks and concluded that the "ulterior purpose" underlying the retention of the checks and their presentation en masse would make such conduct unlawful. ${ }^{35}$ In current terminology, the alleged conduct was "commercially unreasonable."

Similarly, in a very different context, a New Jersey court held that a purchaser who was seeking a release from a contract for construction of a dwelling in a residential subdivision and a return of his down payment could not lawfully bring pressure on the builder to comply with his demands by threatening to resell to an "undesirable" purchaser if the refund were refused. ${ }^{36}$ As in the banking case, the threatened conduct was not in itself unlawful. Presumably, the bank could have delayed presentment of checks for legitimate reasons. Similarly here, the buyer could lawfully have resold the house to any purchaser, including an undesirable one. In neither case was the objective of the challenged conduct unlawful. The reserve bank (it was alleged) wanted the state bank to join the federal reserve system, and the house buyer wanted his deposit returned. Both of these acts would have been entirely lawful. Furthermore, unlike the situation in which the insurer cancelled the dentist's malpractice policy because of his testimony, there was no public policy against the conduct which

33. Id. at 358.

34. Id. The analogy is not exact, of course, because it not only would be lawful but also would or could be in the public interest for the state bank to join the federal reserve system.

35. Id. at 359. The Court further stated that in creating the federal reserve system, Congress did not intend to "sanction" such attacks on state institutions. Id. This statement suggests an ultra vires limitation on the reserve bank's conduct.

36. Wolf v. Marlton Corp., 57 N.J. Super. 278, 154 A.2d 625 (1959). The court observed that the fact that the threatened resale would be lawful did not prevent the threat from being wrongful. Id. at 287, 154 A.2d at 630 . See Restatement of Contracts $\S 492$ (1932). See also Hochman v. Zigler's Inc., 139 N.J. Eq. 139, 50 A.2d 97 (Ch. 1946). 
the reserve bank and the house buyer were attempting to induce on the part of the other party. Nevertheless, the decisions establish that the state bank and the builder could not lawfully be subjected to this kind of pressure. ${ }^{37}$ The drawee bank was entitled to have checks presented to it in a routine manner, or at least not to have them presented in an extraordinary manner for a coercive purpose; the builder had a right not to be forced to return a deposit which it was legally entitled to retain. The illegality of the conduct in each case appears to lie in the effort of one party to influence future conduct by threatening deliberate injury to an existing contractual or property right or business interest of the other party ${ }^{38}$ For the purposes of this article, the significant point is that the exercise of property and contract rights may be limited by basic assumptions of the legal system concerning the use to which these rights may be put. Notions about duress, coercion, unconscionability, good faith, and commercial reasonableness regulate and restrict the exercise of contract and property rights in commercial intercourse. Together, they define the limits of permissible bargaining conduct in commercial dealings and give legal meaning to minimum standards of business morality.

37. The New Jersey court said:

[B]ut where a party for purely malicious and unconscionable motives threatens to resell ... to a purchaser, specially selected because he would be undesirable, for the sole purpose of injuring the builder's business, fundamental fairness requires the conclusion that his conduct . . . be deemed "wrongful," as the term is used in the law of duress.

57 N.J. Super. at 288,154 A.2d at 630.

38. It is difficult to ascertain the grounds for liability in the cases discussed in the text. There is language in the opinions which may indicate that the basis for decision is some type of duress. See Restatement of ContRActs $\$ 492-99$ (I932). "[D]uress going to inotives consists in the threat of illegal acts. Ordinarily, what you may do without liability you may threaten to do without liability." Silsbee v. Webber, I71 Mass. 378, 380 (1898) (Holmes, J.), quoted in Hale, Bargaining. Duress, and Economic Liberty, 43 Colum. L. REv. 603, 618 (1943). However, this formulation does not explain the result in the Federal Reserve Bank case in which Justice Holmes also wrote the Supremc Court's opinion. Further, although RESTATEMENT OF CONTRACTS $\S 493$ (1932), indicates that generally duress involves conduct which is unlawful without regard to the motive of the actor, some of the illustrations of seetion 493 contain examples of threatened conduct which is itself lawful. In some of these the draftsmen conclude that duress is present where the conduct, although not unlawful, is nonetheless "wrongful." Id. § 493(d), Illustrations 5-9, 12-14; id. § 493(e), Illustrations 17-20. In others, duress is not found. Id. $\S 493(\mathrm{~d})$, Illustrations 10 , I5; id. § 493(e), Illustration 21 . In still others, it is concluded that there may or may not be duress. Id. $\S 493$ (d), Illustrations II, 16. No principle for distinguishing the examples is given. In contrast to duress, motive is the principal element in liability under the doetrine of "prima facie tort." It is noteworthy, however, that the courts have had similar difficulty in stating precisely the limits of the liability based on this theory. Appropriate references to current tort materials are contained in W. Prosser, LAW OF TORTS $\S 5$, at 26 (4th ed. 1971). 
III

The Minority Shareholder: Rights vs. Duties

The general propositions developed in parts I and II lead to the principal questions with which this article is concerned: Are there circumstances in which requirements of fairness and good faith in commercial dealings apply to non-controlling shareholders of close corporations in the exercise of their rights as stockholders? May minority shareholders be subject to a duty of loyalty comparable, in some situations, to that imposed on those in control of a corporation? These two inquiries, the first based on the current rhetoric of commercial law and the second phrased in terms of corporate managerial responsibility, present basically the same issues. ${ }^{39}$

In the literature of close corporations, the minority shareholder invariably appears in the role of a victim of majority oppression..$^{40}$ The opposite possibility seems unimportant: There is no need for concern about the oppressive propensities of persons who lack the power of implementation. The duty of loyalty imposed upon majority shareholders in the exercise of their power to control the corporation has been regarded as an exception to the general rule that shareholders are not answerable for the purposes behind their voting or failing to vote their shares. The basis of the exception is the power of the majority to control the enterprise and investment of the minority. However, an examination of the case law reveals that shareholders have not been free to pursue their own interests in total disregard of the interests of the corporation and other shareholders when voting

39. It is arguable that the discussion in the text of a duty of loyalty for minority shareholders should not and need not be limited to closely held corporations. The discussion is limited to the close corporation because the problem of the obstructive minority is most likely to arise in corporations in which the shares are closely held and management is associated with and directly responsible to a majority faction of shareholders. Shareholders in publicly held firms are typically passive investors who follow management recommendations in voting their shares in the usual course of events. Those individuals who lack confidence in management sell their shares. Of course, power struggles and proxy fights do occur, but, partly because of the availability of a public market for shares, the obstruction-avoidance-litigation method of settlement seems less likely to occur. From the standpoint of the expectations of the parties, neither management nor the shareholding public envisions that they are engaged together in a common enterprise to which the shareholders owe any obligation with respect to the exercise of their rights as owners of stock. On the other hand, where stock is held by a few shareholders all of whom are more or less directly associated with the business, the shareholders are likely to view themselves as joint venturers in a common enterprise. There are obviously many situations between these two extreme cases.

40. See, e.g., F. O'NeAl \& J. Derwin, Expulsion or Oppression of Business Associates: "Squeeze Outs" in SMall Enterprises (1961). 
their shares. After reviewing the cases, one writer found that the voteas-you-please "rule" has usually been enunciated by the courts in cases where the challenged vote was not decisive. ${ }^{41} \mathrm{He}$ concluded that the proposition that the shareholder may vote as he wishes is "mere window dressing for the decisive finding that the challenged action is valid and fair." 42

Nor are shareholders free to separate the voting rights of their shares from other aspects of ownership. Voting trusts, the classical device for separating the voting franchise from the other rights of share ownership, are regulated by statute and limited as to duration in almost all states. ${ }^{43}$ Similarly, the courts have looked with disfavor on irrevocable proxies. Like agency relationships generally, a proxy is regarded by the courts as a continuing consensual relationship which is revocable unless the proxy holder has some property or security interest which makes him more than an agent. ${ }^{44}$ These restrictions on arrangements which separate beneficial ownership from voting rights are derived from a fundamental assumption about the corporate franchise. This assumption is that the vote will be exercised by a person interested in promoting the corporation's welfare and the value of the investment represented by the stock. Hence, a contracting stockholder, the corporation, and the corporation's other stockholders are to be protected against arrangements under which control over voting rights and of the enterprise passes to one who has no ownership interest in the shares. The rule against vote selling is merely an illustration of this principle in a particularly obvious and blatant case. ${ }^{45}$

Clearly, the possibilities for irresponsible exercise of a shareholder's prerogatives do not end with irrevocable proxies. ${ }^{46} \mathrm{~A}$ share-

41. See Sneed, The Stockholder May Vote as He Pleases: Theory and Fact, 22 U. PITT.

L. Rev. 23 (1960).

42. Id. at 54 .

43. I F. O'Neal, Close Corporations $\$ 5.09$ (2d ed. 1971).

44. The status of the irrevocable proxy has not been clearly resolved. See, e.g., Ecclestone v. Indialantic, Inc., 319 Mieh. 248, 29 N.W.2d 679 (1947), noted in 47 MiCH. L. Rev. 547 (1949); State v. Pacific Waxed Paper Co., 22 Wash. 2d 844, 157 P.2d 707 (1945). Cf. N.Y. Bus. CoRP. LaW $\S 609$ (McKinney 1963), as amended, (McKinney Supp. 1971). This statute enumerates situations in which an irrevocable proxy may be given. Generally, irrevocable proxies are allowed where the proxy-holder has a direct personal interest in the shares. The section also explicitly prohibits the sale of votes.

45. See. e.g., Palmbaum v. Magulsky, 217 Mass. 306, 104 N.E. 746 (1914). See also cases cited in W. CARY, supra note 7, at 377.

46. Any arrangement which puts the right to vote shares beyond the control of the beneficial 
holder who himself has some ulterior purpose in view may exercise his rights as an owner of stock in a way which is, and is intended to be, detrimental to the business interests of the corporation or the other shareholders. ${ }^{47}$ However, an adverse interest becomes important only when the shareholder's vote determines the outcome of a corporate issue. When the vote of any shareholder is decisive on any question, he is to that extent in control of the corporation.

Minority shareholders are most likely to have a control position where by statute, article provision, or by-law the approval of more than a majority is required for shareholder action. ${ }^{48}$ The purpose of unanimity and greater-than-majority voting requirements is to protect the minority against majority oppression. The veto protects the minority by giving it a degree of control over corporate decisions. As soon as the minority has a degree of control over corporate decision making, however, the question arises as to whether it should not also be subject to a duty of loyalty comparable to that routinely borne by the majority and controlling shareholders. The problem is illustrated in the following examples, both of which are based on cases decided several years ago.

Case $I .^{49}$ Company $A$ was a closely held corporation engaged in the manufacture and sale of bleach. It was not successful, and the majority shareholder, who had managed the business, negotiated an

owner carries a similar risk. Voting trusts are another example which is regulated by statute. See ABA Model Bus. Corp. ACT ANN, $\$ 34$ (2d ed. 1971); N.Y. Bus. CORP. LAW $\S 621$ (McKinney 1963). It would not appear to be difficult to devise an arrangement for the transfer of a limited interest in shares of stock which would be sufficient to avoid the prohibition against transfer of the power to vote alone.

47. For example, see Case II, infra notes 53-55 and accompanying text.

48. The former provisions of the Model Act are fairly typical. The Act required the favorable vote of two-thirds of the outstanding voting shares for amendments of the articles, mergers or consolidation, sales of assets of the corporation other than in the regular course of business, and voluntary dissolution. ABA MODEL BUS. CORP. ACT ANN. $\$ 54(\mathrm{c}), 67,72(\mathrm{c}), 77(3)$ (I960). Except in these special cases, only a majority of a quorum was required, and in the absence of a special provision in the articles, a quorum was a majority of the outstanding shares. $I d$. $\S 30$. The two-thirds requirement was abandoned in the most recent version of the Model Act which requires only an affirmative vote. ABA Model Bus. Corp. ACT ANN. $\$ 59$ (c), 73, 79(c), 84(c) (2d ed. 197I). This morc recent version still provides that a majority of the shares entitled to vote constitutes a quorum. $I d . \S 32$. The Act permits both the quorum and the fraction of the quorum needed for shareholder action to be increased, apparently to unanimity. $I d$. $\$ 143$. Of course, unanimity may be required in fact, as where the shares are evenly divided between two shareholders, or where the minority is large enough to prevent the majority from obtaining the number of votes required for affirmative action under the statute or under an article or by-law provision validly requiring more than a majority for shareholder action.

49. See Matteson v. Ziebarth, 40 Wash. 2d 286, 242 P.2d I025 (I952). 
arrangement under which the business would be taken over by a national manufacturer and distributor of household products. Under the proposal, the majority shareholder of Company $A$ was to be hired by the purchaser for the purpose of developing the market for the company's product. The purchaser demanded an option to purchase all outstanding stock of Company $A$, under a price formula which was fair and reasonable under the circumstances.

Shareholder $X$ of Company $A$ refused to agree to tender his minority shares to the purchaser unless the majority shareholder agreed to pay him a portion of the salary to be paid to the majority shareholder by the purchaser under the proposal. In order to force the tender of $X$ 's share and thereby meet the conditions imposed by the purchaser, Company $A$ was merged into a new corporation, Company $B$, under an agreement whereby the existing shareholders of Company $A$ would receive redeemable preferred shares of Company $B$. The majority shareholder of Company $A$, who held all the common stock of Company $B$, then offered pro rata participation in the Company $B$ common to all shareholders of Company $A$ except Shareholder $X$.

Subsequently, the arrangement was sustained against an attack by $X$, who was limited to his statutory dissent and appraisal remedy under the merger statute. ${ }^{50}$ The proposed arrangement was found to be advantageous to the corporation and fair to all shareholders. ${ }^{51} X^{\prime}$ s attempt to bargain for more than a pro rata share of the total proceeds of the transaction was described as "wholly improper;" 52 yet $X$ was, in fact, merely imposing conditions on which he would tender his stock. The court was not called upon to decide directly whether $X$ could impose such conditions; the issue before it was whether it would interfere on $X$ 's behalf with the proposed merger which would force $X$ to sell his shares at appraised value. On the basis of its conclusion that $X$ 's conduct was un fair, the court declined to interfere with the forced sale which was imposed upon him through the merger.

Case $I I .{ }^{53}$ Company $C$ operated a towing and barge business. Its

50. Id. at 296, 242 P.2d at 1032.

51. Id. at 301, 242 P.2d at 1034. The lower court's finding on this point had been that the proposal "was advantageous not only to the defendant . . . but also to all of the other stockholders of the corporation; . . . this proposal represented the only real chanee for the stockholders . . . to get anything out of their investment." Id. at 300, 242 P.2d at 1034.

52. Id. at 305, 242 P.2d at 1036. The trial court had found that this self-interested purpose was "the real reason for plaintiff's objection" to the transaetion. Id. at 299, 242 P.2d at 1033.

53. See Aiple v. Twin City Barge \& Towing Co., 274 Minn. 38, 143 N.W.2d 374 (1966). 
management decided that more equity eapital was desirable in order to expand the business and sought to increase the authorized capital stock. The necessary amendment of the articles of incorporation was defeated by the vote of Shareholder $Y$, who held more than one-third of the outstanding shares. $Y$ owned two tugs which formerly had been leased by Company $C$. Since the company had discontinued this arrangement and purchased its own equipment, $Y$ had leased his boats to a competing firm in which he had a substantial interest.

In order to circumvent $Y$ 's veto, the board of directors of Company $C$ caused Company $D$ to be organized, and then proposed to transfer $C$ 's shipyard division, which comprised about ten percent of its assets, in exchange for 4,000 of the 50,000 authorized shares of Company $D$. Shareholder $Y$ successfully challenged this arrangement on the ground that it was an improper attempt to circumvent his right to veto an amendment of the articles of incorporation. ${ }^{54}$ The court took the position that the statute gave the owner of more than onethird of the voting shares the right to prevent an amendment of the articles of incorporation, and that his motive in exercising this veto power was irrelevant:

It is unnecessary for us to speculate on the possible effects which might flow from the action of the parent corporation if permitted. It might well be that the plan is constructive from the standpoint of what might be profitable for the stockholders. But we are concerned with legal rights. . . .

If, as it appears, we are faced with the paradox of the minority stockholder using a statute designed for his protection to obstruct and interfere with the best interests of the corporation, the problem is one which should be called to the attention of the legislature.55

It is clear, therefore, that the court recognized that the case did not involve a difference of opinion concerning the best interests of the parent company; the difference was between a majority which was seeking to advance, and a minority which was seeking to hinder, the company's development and profitability.

The contrast in the results in Cases I and II is striking. In Case I, the court permitted a transparent maneuver to succeed in forcing the liquidation of a minority shareholder's equity investment, clearly a gross infringement of an "owner's right." In Case II, a relatively minor reduction in a minority shareholder's degree of control which was in no way detrimental to his interests as a shareholder was pre-

54. Id. at 45,143 N.W.2d at 379.

55. Id. 
vented. In both instances, action which concededly was beneficial to the interests of all the shareholders was proposed. In each case, the minority shareholder was in a position to block the simplest and most direct way of accomplishing the transaction, and did so apparently for reasons which were personal to him and contrary to the interest of the corporation or the other shareholders. There were differences: In Case I, the minority shareholder apparently had tried to overreach the majority by obtaining a side payment to which he had no "equitable" claim; in Case II, the shareholder had committed no such overtly inequitable conduct.

Both $X$ and $Y$ sought equitable relief $-X$ against an arrangement designed to avoid the payment he had demanded, and $Y$ against action intended to circumvent his veto of the initial form of the transaction. In Case I, the minority shareholder's prior offer to withdraw his veto for a price probably weakened his claim for equitable relief and inclined the court to leave him to the statutory dissent and appraisal remedy. One also suspects that if there had been a genuine difference of opinion on the merits of the proposed sale of the company's business, the result might have been different. ${ }^{56}$

The opposing conclusions seem to follow from the differing analytical approaches adopted by the courts in the two cases. In Case I, the court began with the facts and adopted the lower court's finding that from the standpoint of the common interest of the shareholders the proposed sale would be beneficial. In the light of this conclusion, the overreaching conduct of $X$, who was seeking equitable relief on the ground that the available statutory remedy was inadequate, may have been decisive.

In Case II, the court's analysis began with the statutory right of the holder of more than one-third of the shares to defeat a proposed amendment. The next consideration was: Under what circumstances does the statute contemplate that an amendment may be accomplished without shareholder approval? Not surprisingly, the statute was silent on this point, and the way was then open for the court to conclude that allowing the creation of a subsidiary to accomplish the substance of an amendment "would establish a precedent inconsistent with the clear intent of the statute as it presently exists." 57 The result

56. There was case law to support the opposite result. See. e.g., Outwater v. Public Serv. Corp., 143 A. 729 (N.J. Ch. 1928); Eisenberg v. Central Zone Property Corp., 306 N.Y. 58, 115 N.E.2d 652 (1953); Theis v. Spokane Falls Gas Light Co., 34 Wash. 23, 74 P. 1004 (1904).

57. 274 Minn. at 46,143 N.W.2d at 379. 
of the court's decision is that the minority veto power not only reaches amendments but also in some cases reaches transactions which could be accomplished by a variety of routes including amendment of the articles. ${ }^{58}$ The process of treating both amendment and alternative tactics in a similar fashion leads finally to the conclusion that the motives of the minority are not relevant in either situation. (One wonders whether the result would have been different if the majority had first attempted to create the subsidiary without the prior abortive attempt to amend the articles.)

The fundamental question posed by these cases is: What duties (if any) should the law impose upon a minority shareholder in the exercise of legal rights attached to his stock? The court in Case II took an expansive view of the minority shareholder's rights. A comparable approach in Case I would have led the court to conclude that the minority shareholder's refusal to sell his stock could not be circumvented by a merger arranged solely for the purpose of forcing the sale of his shares. ${ }^{59}$ Under this view of the shareholder's right to withhold his shares, there would be no impropriety in his setting practically any condition on sale. Reaching the opposite conclusion, the court in Case I did not, and did not need to, decide directly that $X$ had an obligation to offer his shares at the price acceptable to the other shareholders. But this propostion is suggested indirectly by the court's refusal to strike down a transparent maneuver which was

58. The alternative tactic aspect of Case I closely resembles the de facto merger situation. In substance, two separate incorporated enterprises can be combined and continuity of ownership preserved in any onc of three ways: (1) through a statutory merger of consolidation; (2) through a sale of the assets of one for stock of the other; (3) through an exchange of stock of one for stock of the other. Under the Model Act, dissenting shareholders have appraisal rights under the first and second alternatives, but not under the third. ABA MODEL BuS. CORP. ACT ANN. $\$ 80$ (2d ed. 1971). The de facto merger doctrine preserves the appraisal right in the third case. See, e.g., Applestein v. United Board \& Carton Corp., 60 N.J. Super. 333, 159 A.2d 146, aff'd, 33 N.J. 72, 161 A.2d 474 (1960). Courts following the opposite view regard each separate procedure as independent, and confine the shareholders to their rights under the form of the transaction selected. See Hariton v. Arco Electronics, Inc., 182 A.2d 22 (Del. Ch. 1962), aff'd, 188 A.2d 123 (Del. 1963) (Delaware law gives dissenters appraisal rights only in situation (1). Del. Code ANN. tit. 8, $\$ 262$ (Supp. 1968)).

59. The bargaining tactics available to a minority vary with the size of its shareholdings. In Case 1, if $X$ had held $34 \%$ of the shares of Company $A$, the majority could not have mustered the two-thirds vote necessary for the corporate action, could not have forced the merger over his objection, and would have had to bargain with him. On the other hand, such an increase in the size of $X^{\prime}$ s investment, would have greatly increased the amount of his loss had he caused the deal to fail. This greater risk would have given him a larger personal incentive not to jeopardize a transaction which was in the common interest of all of the shareholders. A larger stake on $X^{\prime}$ 's part could therefore have increased the chances of a voluntary settlement. 
intended to force the minority shareholder alone to sell for the appraisal price.

The result in Case I is not significantly different from that reached in the cases in which courts have examined the exercise of commercial contract and property rights to determine whether a party's conduct is consistent with applicable standards of good faith and commercial reasonableness, or whether it is "unconscionable." The rule of the decision seems to be that at some point the law will protect the majority against an attempted exercise of ownership rights by a minority shareholder, at least to the extent of denying equitable relief to one whose conduct is merely an effort to take financial advantage of the other shareholders. ${ }^{60}$ It must follow that, to some extent, the minority shareholder has a duty not to seek "unfair" advantage over his associates.

Case I sharply presents the conflict between fiduciary responsibility and rights of property ownership. Of the bundle of rights which comprise share ownership, the right to retain one's investment in the enterprise is most basic and obvious. Where an exercise of this right deprives other shareholders of a chance for an advantageous sale of their shares, a bargaining situation arises in which the hold-out has a very strong position. Of course, bargaining behavior inevitably occurs when differences of opinion arise among shareholders in closely held corporations. Commentators have long urged that minority shareholders should obtain a veto through high quorum and voting requirements, through pooling agreements, or in some other manner, to protect themselves against majority oppression. ${ }^{01}$ These arrangements give the minority leverage to protect its interests when dissension arises. The idea is that when each party occupies a legally forti-

60. See Stokes v. Continental Trust Co., 186 N.Y. 285, 301-03, 78 N.E. 1090, 1095-96 (1906) (dissenting opinion). Stokes is a leading case dealing with pre-emptive rights. It involved a situation in which a company's articles of incorporation had been amended in order to create additional shares for the express purpose of sale to an outside group for several times par value. The amendment and sale were in fact beneficial to all existing shareholders, whose shares greatly increased in market value as a result of the transaction. The court nevertheless held that a plaintiff possessing pre-emptive rights was entitled to purchase his prorated portion of the new issue, at the price paid by the outside group. The dissenting judge characterized the plaintif's conduct as "simply an attempt to make something out of his associates." Id. at 303, 78 N.E. at 1096 . The case illustrates a situation in which a minority shareholder was enabled to assert a property right attached to his shares and to profit personally at the expense of his co-owners.

61. The various aspects of arrangements to deal with these problems are extensively treated in I F. O'NeAL, supra note 43, $\$ 3.01-7.29$. Professor O'Neal also reviews devices to avoid and to break deadlock. See $i d$. $\$ \S 9.01-.31$. 
fied position, opposing shareholders will be forced by their common interest in profit to reach a mutually acceptable arrangement. (One cannot tell the extent to which this actually does happen by examining case reports.)

Where no agreement is reached between the parties to a bargaining situation, and each party occupies a legally secure position, there is a standoff. In Cases I and II such an impasse occurred, and litigation resulted from the majority's attempt to break the stalemate. It is possible, of course, for a stalemate to occur in any bargaining situation, but the likelihood of a stalemate is increased where there is a wide disparity in the stakes for each side. In Case I, because the minority had relatively little at stake in the corporation, the risk of the loss of the sale of the business had relatively little impact on Shareholder $X$; yet the same uncertainty may have threatened financial disaster to the majority shareholder. In Case II, although failure to implement the proposed subsidiary arrangement would have resulted in limiting the growth of the company's business, it would not have threatened Shareholder $Y$ 's existing investment and presumably would have benefited his competing business interest.

Ultimately, both examples are buy-out cases: The question in each is what price can the minority force the majority to pay for its shares? To the extent that the minority can prevent management and the majority from implementing corporate policies and decisions, the minority can put pressure on the majority to raise the price that it will be willing to pay to buy out the minority. The litigation in each case is a price-setting mechanism in which the limits of permissible bargaining tactics of both sides are determined. The minority's bargaining tactic is obstruction, and the majority's is avoidance or evasion of the obstruction. In Case- I the formal question of law was whether the defendant could implement a merger which was really a device to force the sale of the minority's stock; in Case II it was whether the court would extend the minority's veto power over amendments to a "de facto amendment" accomplished through the creation of a subsidiary. In the first instance the avoidance tactic was permitted, at least partly because of the court's view that the minority's prior bargaining conduct was improper. This decision settled the dispute by determining that the highest price the minority shareholder could get for his shares was the statutory appraisal value. The decision in Case II did not fix the maximum value of the minority's shares and did not settle the dispute. It strengthened the minority shareholder's position in future bargaining and greatly increased the 
buy-out value of his shares. As a result of the case, the majority had three choices: (1) to abandon its plan for corporate expansion; (2) to attempt to devise another way to circumvent the minority's obstruction; or (3) to negotiate for the purchase of the minority's stock-presumably at a price which would reflect the value to the business in which the minority shareholder had a competing interest, of the shareholder's power to block the expansion of Company $C .^{02}$

When disputes arise in close corporations, all of the rights which the parties have as owners of stock become bargaining counters. When in particular situations the courts decide that the use of certain "rights" will not be permitted, rules are being laid down for the settlement of disputes within enterprises. And it is unavoidable that in making such rules, the courts will be influenced by their view of the conduct and motives of the participants. Those views, in turn, are certain to be influenced by general notions of good faith, commereial reasonableness, and unconscionability.

The operation of these factors is quite clearly visible in the judicial dissolution cases. As the reader is undoubtedly aware, almost all states have statutes empowering the courts to order dissolution under certain circumstances because of deadlock. ${ }^{63}$ The power is always discretionary and courts have often been reluctant to exercise it.04 One commentator has noted that "judieial reluctance" to order dissolution is based on recognition of the fact that "dissolution irrevocably ends a formerly viable concern." 65 This judicial attitude reflects the view that destruction of solvent enterprises is generally undesirable from the standpoint of both the public interest and the interest of the parties directly concerned. However, this analysis fails to take adequate account of the dynamics of the bargaining process in intracor-

62. There is obviously some price at which Shareholder $X$ would sell his shares to Company $C$ or its other shareholders, and they would plainly like to be rid of him. Presumably, $X$ would be willing to sell his $C$ shares at any price which exceeded his pro rata interest in the going concern value of Company $C$ plus the value to his investment in the competing firm of his power to hinder the competition provided by Company $C$. It is interesting to note that if Company $C$ were a partnership, $X$ 's conduct would clearly be an actionable breach of $X$ 's fiduciary duty to the firm. See J. Crane \& A. Bromberg, supra note 7.

63. The Model Act provision is typical. See ABA Model Bus. Corp. Act ANN, $\S 97$ (2d ed. 1971).

64. A leading case is Radom v. Niedorff, Inc., 307 N.Y. 1, 119 N.E.2d 563 (1954), where the court speaks of "judieially imposed death." Id. at 7,119 N.E.2d at 565 . For a similar result in a state following the Model Act, see Jaekson v. Nicolai-Neppach Co., 219 Ore. 560, 348 P.2d 9 (1959). Cf. Strong v. Fromm Labs., Inc., 273 Wis. 159, 72 N.W.2d 389 (1956).

65. Folk, Corporation Statutes: 1959-1966, 1966 DukE L.J. 875, 952. 
porate disputes. Dissolution litigation is a bargaining tactic. Once it is settled whether or not one party can compel dissolution, the stage is set for final bargaining on the price of his shares. ${ }^{66}$

In the dissolution cases, as in Cases I and II, the underlying issue is what limits should be placed on the bargaining tactics used by the competing factions in disputes among shareholders in close corporations. The literature dealing with these disputes has been primarily concerned with majority oppression. ${ }^{67}$ Because the majority usually has control, the means available to it for oppressing the minority are many and varied, including such policy matters as salary and dividend policy, which may be manipulated to exclude the minority from the benefits of ownership. ${ }^{65}$ On the other hand, the minority generally has at its disposal two weapons which may be used, as the foregoing examples illustrate, both offensively and defensively. It may block transactions for which its approval is required, and it may withhold its shares where their tender is necessary to conclude a transaction.

Upon what grounds should the courts base a determination of whether or not a particular exercise of a shareholder's prerogatives in an intracorporate dispute is lawful? The foregoing discussion presents a paradox. The argument on the one hand is that in disputes between owners of the enterprise, each faction may freely use for its own benefit all the rights attached to the block of shares which it holds. On the other hand, the argument is that the validity of the exercise of rights of share ownership in some circumstances is dependent upon the purposes for which the rights are exercised. ${ }^{69}$

66. It is difficult to document this point quantitatively. However, in a number of reported cases, disputants reached agreement after a court determined whether one party could compel dissolution. See Hetherington, Special Characteristics, Problems, and Needs of the Close Corporation, 1969 U. lLL. L.F. 1, 11 n.44, 20 n.73. Settlement rather than dissolution probably follows the determination of most cases in which judicial dissolution is sought. The reason is obvious: If the business can be operated profitably, it is in everyone's interest that it should continue to be operated either by one of the disputants or by a purchaser.

67. See note 40 supra.

68. The voluminous periodical literature on various close corporation problems is extensively cited in H. HENN, supra note $3, \$ 257-90$. The theme that ties the area together is the protection of the minority against majority oppression.

69. Generally, corporation statutes are silent on the purposes for which rights given to shareholders may be exercised. For example, a shareholder may dissent from a proposed merger or sale of assets for any or no reason and demand payment of the appraised value of his shares. ABA MODEL Bus. CORP. ACT ANN. $\$ 80-81$ (2d ed. 1971). The only statutory right of shareholders under the Model Act which is expressly conditioned on its being exercised for a legitimate purpose is the right to inspeet books and records. Id. $\S 46$. This section provides that inspection is available "for any proper purpose." Purposes which are personal to the 
To resolve this apparent inconsistency, it is necessary to distinguish between two separate types of disagreements. The first is a dispute concerning the merits of a particular corporate decision or policy. The question in such cases is whether a particular course of action is wise and should be adopted. In disputes of this kind the majority is entitled to follow the course it thinks best, despite the most earnest disagreement by the minority. $\mathrm{He}$ who has the votes makes policy. The second type of case arises where there is in fact no disagreement between the parties on which decision is in the best interest of the enterprise, but, nevertheless, one faction elects to block the transaction for personal reasons having nothing to do with the merits of the decision. Cases I and II both illustrate this type of case. In the first, the minority shareholder placed the common interest in jeopardy by demanding a side payment as the price of his cooperation. In the second, the minority shareholder appeared to be using his investment in Company $C$ as a device for advancing his competing business interest by preventing the growth of $C$.

Conduct on the part of the majority similar to that engaged in by the minority in Cases I and II would be unlawful. The law is settled that once a policy or decision has been adopted, the majority may not appropriate to itself a disproportionate share of the proceeds; $;^{70}$ nor may the majority sacrifice the corporation's business interests to an outside competing interest. In both of the cases discussed, minor-

shareholder but adverse to the interest of the firm, such as obtaining trade information useful to a competitor, are improper. See H. HENN, supra note $3, \S 199$, at 397 . The apparent purposc of the statutory restriction is to limit the exercise of the right to inspect to situations in which the inspecting shareholder is seeking to advance or protect the intcrests of shareholders as a group. The purposes of the minority shareholders in the principal cases, being both personal and apparently adverse to the common interests of all shareholders, would probably not be proper if the minority had been secking to exercise rights under a statute protecting the interests of shareholders acting "for proper purposes."

70. Cases involving this problem generally arise in connection with a sale of the corporation's business or assets, or of the controlling block or perhaps all of the shares. If the majority receives more than its proportionate share of the total proceeds where all shares are sold, or if the price received for its shares exceeds their reasonable asset or going concern value on the sale of its shares alone, the possibility of an unlawful premium is present. See the cases and references to the current literature in W. CARY, supra note 7, at 827-47. For a general statement and application of the expanding view of the majority's responsibilities in such situations, see Note, Jones v. Ahmanson: The Fiduciary Obligations of Majority Shareholders, 70 Colum. L. REv. 1079 (1970). In a recent private sale of the controlling block of shares in a large California corporation, the seller procurcd from the buyer an offer to take minority shares at the same price. Counsel for the seller advised this writer that in their view a holding imposing an obligation on the selling majority shareholder to obtain such an offer in the case of a private sale was "entirely probable" in California. 
ity interests were attempting to do exactly what the majority may not do. Further, the means employed by the two minority shareholders involved the use of the minority's power to control corporate action in a particular situation, a use of the power of control which would clearly be unlawful on the part of the majority.

Efforts to obtain a disproportionate share of the value of a corporate enterprise should be accorded the same treatment whether the attempts are made by the majority or the minority. Conduct by any shareholder which is intended to be detrimental to the welfare of the enterprise or to subordinate its business interests to competing business interests of the shareholder is a breach of a duty of loyalty which all shareholders owe to the common venture. As far as minority interests are concerned, this proposition merely amounts to saying that where the minority's conduct makes a difference, it ought to be equally accountable for its behavior and motives as the majority.

In other commercial contexts, as we have observed, the exercise of contract and property rights for retaliatory or other "improper" purposes may be constrained to protect the interests and reasonable expectations of other individuals to whom no fiduciary obligation is owed. The same line of reasoning suggests with greater force that, in closely held companies where the shareholders are bound together by a community of interest, the deliberate exercise of property rights to the detriment of the common purpose is not a legally permissible exercise of the shareholder's powers. The courts have developed a large body of precedent for the purpose of insuring that the majority in controlling the enterprise will seek to promote the common interest;:". the majority is entitled to a similar assurance in cases where circumstances have placed effective control in the hands of the minority.

71. The classic cases from which the scope of the majority's duties are developed are, of course, well known. Notable among them are Perlman v. Feldmann, 219 F.2d 173 (2d Cir. 1955) and Gerdes v. Reynolds, 28 N.Y.S.2d 622 (1941), which are familiar to generations of law students. And more recently, the development of the majority duties was expanded in a somewhat different direction in Jones v. Ahmanson, I Cal. 3d 93, 460 P.2d 464, 8 I Cal. Rptr. 592 (1969). In this case the majority in a closely held corporation was found to have an obligation to permit minority shareholders to share in a public market for the shares of the corporation which the majority had created through a holding company. The scope of the direct obligation between the majority and minority, not involving direct corporate action by the majority, is yet to be developed. See generally Note, supra note 70 . 


\section{CONCLUSION}

It is impossible to devise an all-inclusive formula which defines the scope of shareholder rights and the limits of intracorporate bargaining in precise terms. Each shareholder is entitled to assume that the other shareholders will not intentionally exercise their rights as owners for the purpose of damaging or destroying the common venture. A minority shareholder could not rationally make any other assumption, bccause his investment is continually subject to decisions of other individuals over whom, in the absence of special provisions in the articles or by-laws, he has no control. Loyalty is therefore the surrogate for control, and the courts have been alert to protect the minority in its unavoidable dcpendence on the majority. The reason that the idca of minority loyalty seems novel is that the minority position affords less opportunity for abuse. However, such opportunities do arise, and in such cases the policies underlying the fiduciary responsibilitics imposed on those who have control should be applicable to any shareholder whose vote or other conduct as a shareholder is in fact controlling in the particular situation.

In spite of the apparent and inevitable imprccision of such criteria for evaluating commercial behavior as good faith, commercial reasonableness, and unconscionability, the courts have moved toward imposing minimum rcquircments of fair dealing in nonfiduciary business situations. The similarly imprecise concept of fiduciary responsibility, at lcast as applied to majority shareholders, has not caused the courts great difficulty, and it has clearly promoted fair dealing within business enterprises. The majority may not exercise their corporate powers in a manner which is clearly intended to be and is in fact inimical to the corporate interest, or which is intended to deprive the minority of its pro rata share of the present or future gains accruing to the cnterprise. A minority shareholder whose conduct is controlling on a particular issue should be bound by no different standard. 